\title{
OBSERVATIONS ON THE PROVISIONING BEHAVIOR OF AMMOPHILA ABERTI HALDEMAN (HYMENOPTERA: SPHECIDAE)
}

\author{
By F. D. Parker, V. J. Tepedino, and D. L. Vincent* \\ Bee Biology \& Systematics Laboratory Agricultural Research \\ Science \& Education Admin., USDA \\ Utah State University, UMC 53 \\ Logan, Utah 84322
}

\section{Introduction}

Nest-building aculeate Hymenoptera construct a variable number of cells within each nest; a single egg is laid in each cell by the nesting female who also supplies sufficient food for the development of her offspring. The sequence of oviposition and food provisioning may vary from oviposition followed by prey stocking (e.g., Odynerus), to oviposition on the initial prey item followed by additional provisioning (e.g., Ammophila), to oviposition after all food has been stocked (most bees).

The manner of provisioning is also quite variable in those species that supply the offspring with more than one prey item. Evans (1966) delimited three basic types of provisioning behavior which are thought to form an evolutionary sequence: 1) mass provisioning, in which prey are brought to the cell in rapid succession and the cell is completed before eclosion of the egg; 2) delayed provisioning, in which prey are sometimes stocked over a longer period of time due to environmental circumstances, and egg eclosion occasionally occurs before provisioning is completed; and 3) progressive provisioning, in which prey are provided over an extended period of time, and the offspring pass through several larval instars before the final prey item is presented and the cell sealed. Evans (1966) further subdivided progressive provisioning into two additional categories but noted that this distinction was not clear-cut. For our purposes it is sufficient to treat progressive provisioning as a single category. Progressive provisioning is thought to reduce offspring mortality caused by parasites and predators, because the adult female is able to spend

*Present address: USDA-SEA, AR, Beneficial Insect Introduction Laboratory, Building 417, BARC-East, Beltsville, Maryland 20705

Manuscript received by the editor January 8, 1981. 
more time guarding her nest (Evans 1966). In addition, Malyshev (1968) suggested that prey items are fresher and less likely to be unsuitable to offspring when supplied progressively.

The genus Ammophila is interesting because it encompasses the evolutionary transition from oviposition upon a single prey to progressive provisioning (Evans 1959, Powell 1964). Studies of representative species can clarify the successive steps in the evolution of a more complex behavior, i.e., progressive provisioning, from its simpler antecedents. Here we report on the method of provisioning followed by Ammophila aberti Haldeman, a species suspected of practicing delayed or progressive provisioning (Hicks 1932, Evans 1959, Powell 1964). In addition, we provide data on prey records, egg placement, and report observations that suggest facultative cleptoparasitism.

\section{Study Site and Methods}

A small nesting population of $A$. aberti ( 12 females) was observed at Greenville Farm (GF), an agricultural experiment station operated by Utah State University in North Logan, Cache County, Utah. In contrast to a report by Hicks (1932) that $A$. aberti is bivoltine at Boulder, Colorado, this species is univoltine in northern Utah and flies from the first half of July to late August. Our observations were made on three consecutive days beginning 23 July and then sporadically through 4 August.

The wasps nested in three bare, moist $6 \mathrm{~m}^{2}$ soil beds that were prepared and maintained for a population of alkali bees (Nomia melanderi Cockerell; Bohart 1972). The beds were surrounded by experimental plantings of alfalfa, sugarbeets, wheat, and vegetable crops. Wasps were marked with acrylic paints on various parts of the body, and their nests were marked with similarly painted toothpicks. We also applied dots of paint to the plugs of closed nests to determine if nests were visited during our absence.

Nests at GF could not be excavated without disturbing both the wasps and alkali bees that used the beds. Instead, we excavated nests of $A$. aberti from a large population that nested in a 1 ha alkali flat at Cornish, Utah, $40 \mathrm{~km}$ northwest of GF. Soil at Cornish was mostly bare with some patches of pickleweed (Allenrolfea occidentalis (S. Wats.) Kuntze) and moist because of seepage from a nearby irrigation ditch. An alfafa field bordered the nesting site on one side and halophytic shrubs (e.g., Sarcobatus, Cercocarpus, Atriplex) on 
the other sides. Nests were excavated immediately after their completion. All prey items were collected for subsequent identification.

Results

Nesting activity-Nesting activity varied greatly among female wasps. During the first week of observation at GF, four marked females did not nest at all. Although they were frequently seen flying around the beds and investigating the soil surface, they were absent for long periods of time and may have nested in other areas. Those wasps that did dig in the beds also showed considerable variability in their nesting activity: two females began five nests each; two others began eight nests each; and the remaining four began $1,3,4$, and 12 , respectively.

Many of the nests that were initiated were terminated prematurely, before provisioning began. We observed complete provisioning and nest closure for only $10(22 \%)$ of the 46 nests begun by the eight females. Because of our occasional absences from the nesting site, we probably missed the provisioning and completion of some other nests; but we are convinced that many of the nests were abandoned prior to provisioning. On numerous occasions, females dug nests, plugged them, and never subsequently disturbed the paint marks on the plugs. All abandoned nests were plugged with pebbles and soil. Hicks (1932) and Powell (1964) also noted that female A. aberti sometimes abandoned nests, and Brockmann and Dawkins (1979) recently reported high percentages of nest abandonment by Sphex ichneumoneus L., another ground-nesting sphecid wasp.

Abandoned nests were frequently reinspected briefly by their builders. Inspection occurred at least once per day, usually for two or three days subsequent to abandonment, and was restricted to examination of the closing plug. In only four cases was an abandoned nest reopened, and three of these reopenings were by one wasp, Silver, whose behavior was also atypical in other respects (see below). Provisioning-The suggestion that $A$. aberti practices delayed or progressive provisioning is based upon limited observations and a few nest excavations: Hicks (1932) noted that some females took up to seven days to provision their nests (he also notes that others provisioned rapidly) and that the larva is sometimes large "before the final victim has been placed before it"; Evans' (1959) excavations of two nests plus observations that one female took at least two (and 
probably three-to-four) days to provision one nest; Powell's (1964) excavations of five nests.

Two lines of evidence suggest that $A$. aberti does not practice delayed or progressive provisioning in northern Utah. First, preycollecting trips at $\mathrm{GF}$ were generally rapid $(\overline{\mathrm{x}}=45.8 \mathrm{~min}, \pm 35.0$, range 10-168 $\mathrm{min}$ ) and at least two prey (and usually more) were collected in succession. We have data for five nests from the initiation of digging through provisioning and final nest closure: two nests took more than one day from initiation to completion ( $40,48 \mathrm{hrs})$, but both were constructed and provisioned during a period that included a day of rain when neither female was active; the other three nests required an average of $24 \mathrm{hrs}(21,24,27 \mathrm{hrs})$ for completion. Thus, nests typically were not provisioned over an extended period of time as would be the case if progressive provisioning were practiced.

The second line of evidence against progressive provisioning comes from the nest excavations at the Cornish site. Nests were excavated immediately after final closure: if progressive provisioning was practiced, most nests should have contained either third or fourth instar wasp larvae or an unhatched egg with one or two prey. This was not the case. Of 50 nests excavated, 30 contained unhatched eggs attached to larval prey, two contained eggs that had just hatched that day, 12 had young (first or second instar) larvae, and only one each had medium (third instar) or large (fourth instar) larvae. Four nests had prey but no egg. Cells averaged about six prey per cell (Table 1). Prey records-Fourteen genera of prey in five families of Lepidoptera were recorded from the 50 nests excavated at Cornish (Table 1). This contrasts with previous reports that $A$. aberti provisions its nests exclusively with geometrids (Hicks 1932, Evans 1959, Powell 1964; Evans reported finding a few hesperiids also). Members of the family Pieridae were the most abundant prey items; $52.5 \%$ of all prey were pierids and at least one pierid larva occurred in $74.0 \%$ of the nests. Noctuids were also well represented and accounted for $32.4 \%$ of all prey individuals and were found in $38.0 \%$ of all nests. The most abundant genera of prey were Colias eurytheme (Pieridae), a species near Drasteria sp. (Noctuidae), and Pieris (both rapae (L.) and protodice Boisduval \& LeConte). Most nests contained a single species of prey $(68.0 \%) ; 20 \%$ of all nests contained two species and $12 \%$ contained three species of prey. Thus, $A$. aberti, is not restricted to geometrids as prey items and a substantial number of nests (32.0\%) are provisioned with two or more prey species. 
Table 1. Prey records from 50 Cornish nests. Total number of nests exceeds 50 because more than one taxa frequently occur in same nest.

\begin{tabular}{ccccc} 
& \multicolumn{2}{c}{ Total } & Percent & Total \\
Taxa & Larvae & Nests & Larvae & Nests \\
\hline
\end{tabular}

Geometridae

Nr. Anacamptodes

Nr. Caripeta $\# 2$

Nr. Semiothisa

Geometrid \#2

Total

$\begin{array}{rrrr}19 & 3 & 6.7 & 6.0 \\ 15 & 3 & 5.3 & 6.0 \\ 4 & 1 & 1.4 & 2.0 \\ 2 & 1 & 0.7 & \frac{2.0}{14.0}\end{array}$

Hesperiidae

Pyrgus communis (Grote)

Pholisora catullus (F.)

$\begin{array}{llll}1 & 1 & 0.4 & 2.0 \\ \frac{1}{2} & \frac{1}{2} & \frac{0.4}{0.7} & \frac{2.0}{4.0}\end{array}$

Noctuidae

Nr. Drasteria

Nr. Toxocampa

Nr. Acontia

Ogdoconta cinereola (Guenée)

Amphipyrinae

Peridae

Pieris spp.

Colias eurytheme (Boisduval)

$\begin{array}{rrrr}80 & 16 & 28.2 & 32.0 \\ 1 & 1 & 0.4 & 2.0 \\ 5 & 1 & 1.8 & 2.0 \\ 2 & 1 & 0.7 & 2.0 \\ \frac{4}{92} & \frac{1}{19} & \frac{1.4}{32.4} & \frac{2.0}{38.0}\end{array}$

Pyralidae

Loxostege sticticalis $\mathrm{L}$.

$\begin{array}{rrrr}38 & 10 & 13.4 & 20.0 \\ \frac{111}{149} & \frac{30}{37} & \frac{39.1}{52.5} & \frac{60.0}{74.0}\end{array}$

$\begin{array}{llll}1 & \frac{1}{1} & \frac{0.4}{0.4} & \frac{2.0}{2.0}\end{array}$

Egg placement-We recorded the area of egg placement on the prey larvae for 28 of the 31 unhatched eggs excavated from nests at Cornish. Four eggs were placed on the thorax (two between the first and second segments and one each on the first prothoracic segment and between the first and second segments); 24 eggs were placed on the abdomen (seven each on the first and second segments, two on the third segment, three on the fourth segment, and five on the first proleg; two eggs were laid in one cell).

Cleptoparasitism and prey stealing-In sume species of aculeate Hymenoptera, females no longer build nests or forage for food for their offspring. Instead, the nests of females of other species are located and the food stored by these hosts is utilized to rear the 
offspring of the cleptoparasite (Wheeler 1919, Evans 1966, Bohart 1970, Eickwort 1975). Facultative cleptoparasitism, in which females occasionally usurp the nests of conspecifics rather that females of other species, is thought to be the initial step in the evolution of obligate cleptoparasitism. Examples of facultative parasitism have been reported for several species (Alcock 1975, Eickwort 1975) but not for $A$. aberti.

During our observations at GF, one female, Silver, exhibited cleptoparasitic behavior. At $1250 \mathrm{hrs}$ on $23 \mathrm{July}$, she opened a nest that was being provisioned by another female, Yellow Legs, while the latter was out foraging, removed a single larva, stung it several times, dropped it outside the nest entrance, and re-entered the nest. At this point the nest owner returned, forcibly evicted Silver and soon permanently sealed the nest; the larva removed by Silver was left outside the nest. Curiously, immediately after the nest was permanently sealed, Silver returned and performed a similar sequence of sealing behaviors.

Soon after this sequence was completed, Silver located another nest that had just been finished by White. Silver opened this nest, removed four larvae, one at a time, and deposited them adjacent to the burrow entrance (Fig. 1). At this point, White returned and Silver was again forcibly evicted, and the burrow then sealed by White without returning the larvae to the nest (Fig. 2). As soon as White had departed, Silver returned, reopened the nest, and removed two more prey. Silver then grasped each larva in turn, flew off a distance of about $3 \mathrm{~m}$, landed either on the ground or a fence post (Fig. 3), stung the prey, and then returned to White's burrow and took the larva inside (Fig. 4). After all six larvae were treated in this manner, the nest was sealed and never reopened. It is possible that the egg originally deposited by White was dislodged during this sequence, although we have no evidence of this, nor do we know if Silver ever deposited an egg of her own.

Prey stealing was observed on several occasions during our excavations at the Cornish site. In several instances, prey-laden females were attacked as they returned to their nests from foraging trips. Typically, several other females would pounce upon the preyowner; in the ensuing struggle, one of the attackers would fly off with the prey which was dropped as the female attempted to defend herself. The stolen prey was typically carried off for several meters, 

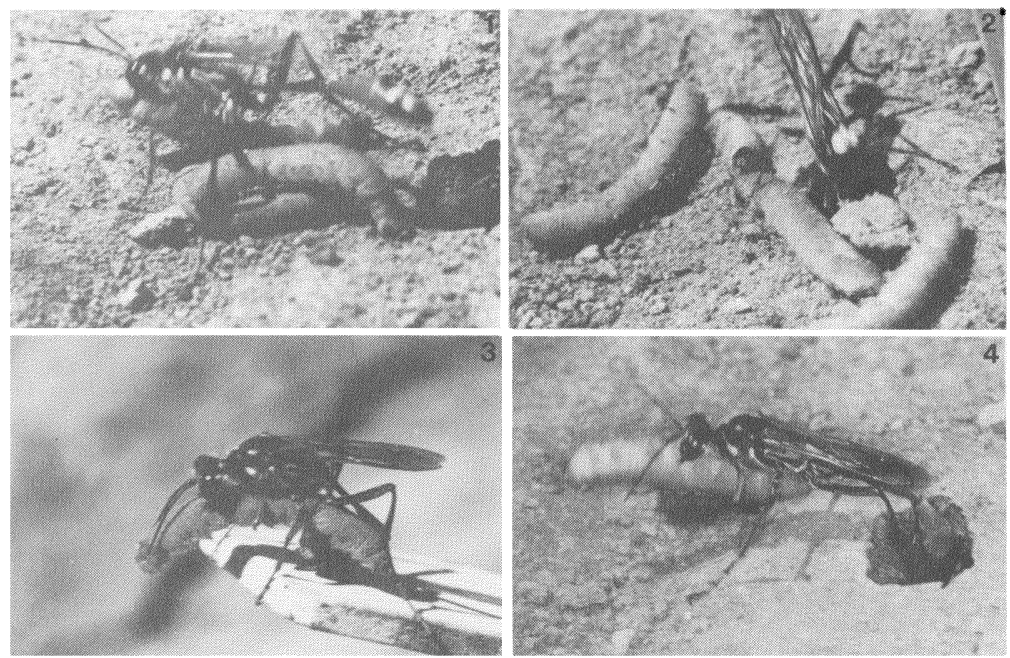

Figures 1-4. Fig. 1. Silver removing prey from White's nest after opening it. Fig. 2. White begins to replug the burrow after evicting Silver. Note that prey have not been returned to the nest. Fig. 3. Silver stings one of the prey which she has carried to a nearby fence post. Fig. 4. Silver returning the last of the prey to White's nest.

stung, and then carried into the thief's burrow. Victimized females usually flew off after escaping their attackers. Because females were unmarked, it was not clear if the same wasps did all or most of the attacking or if the attackers ever foraged for prey in the field.

\section{Discussion}

Evans (1959) classified $A$. aberti as a delayed (rarely mass) provisioning species. Powell (1964) agreed but also suggested that progressive provisioning might occur. In contrast, our observations and nest excavations strongly suggest that $A$. aberti is primarily a mass provisioning species, at least in northern Utah. At the Cornish site, only two of 46 nests excavated immediately after completion contained larvae that were beyond the second instar while 30 nests contained eggs that had not yet hatched. In addition, observations at GF showed that wasps rapidly completed digging and provisioning their nests and did not reopen them after completion.

Nevertheless, 14 nests $(30.4 \%)$ did contain first or second instar larvae when excavated, and these nests do fit Evans (1966) definition 
of delayed provisioning. Any of several possibilities might explain this relatively high incidence of "delayed" provisioning. The first is that the population is behaviorally polymorphic for the provisioning trait(s), i.e., that both mass and delayed provisioning behaviors currently exist. A second possible explanation is inter-individual variability in the speed with which prey can be found, subdued, and returned to the nest. Nests that appear to have been provisioned on a delayed basis may simply be the work of individuals that are less efficient at hunting than others. Our data are not detailed enough to allow additional discussion of these possibilities.

A third (and more likely) explanation is that $A$. aberti is a mass provisioning species but that the rate of provisioning is influenced by environmental circumstance. As Evans (1966) points out, the distinction between mass and delayed provisioning is a tenuous one. Indeed, if provisioning is delayed merely because of inclement weather (as were two nests at GF) or temporary paucity of prey as Evans (1966) suggests, then any distinction between mass and delayed provisioning is artificial. Proof of delayed provisioning requires that the insect delay its pace of provisioning even when prey are abundant and weather conducive to flight, and $A$. aberti does not appear to do this in any consistent way. Hicks (1932) also reported that nests were sometimes completed rapidly and at other times slowly but offered no explanation for these differences.

It is not clear why females abandon so many nests. Brockmann \& Dawkins (1979) found that many of the nests abandoned by the female Sphex ichneumoneus were later used by other females, and they concluded that if abandonment was due to unsatisfactory substrate or nest location, these conditions must have been temporary. In the small population we studied, abandoned nests were not re-used later. Tsuneki (1963) and Evans (1966) have suggested that the "false" burrows constructed adjacent to the main nest entrance by several digger wasp species may serve to decoy parasites. Conceivably, abandoned nests could serve the same purpose, but as Brockmann and Dawkins (1979) have pointed out, decoys would have to benefit the females that dug them more than other unrelated members of the population. This might be the case if females tended to cluster their nests within a relatively restricted area. Then enemies that invaded abandoned unrewarding nests might be discouraged from additional searching in the immediate area (Tepedino et al. 
1979). Some female $A$. aberti did construct all their nests, both abandoned and completed, in the same area of one of the beds. For example, Yellow Legs clustered all twelve of her nests in bed 1, while White Thorax split her eight nests between local areas in beds 1 and 2 . Silver was, again, atypical; she divided her eight nests almost equally among three beds. Thus, in some cases abandoned nests may be of use in deterring enemies, but this suggestion requires further study.

Equally perplexing was the reinspection of nests for several days after they had been completed or abandoned. Reinspection cannot be explained as a result of conditioning to return to the new nest by way of the older ones, because it did not occur on every return trip to the new nest. One possibility is that females inspect older nests externally as a means of assessing the incidence of disturbance, i.e., enemies in the area, and then use this information to "decide" whether or not to move to other nesting areas.

\section{ACKNOWLEDGEMENTS}

We are indebted to D. M. Weisman, Systematic Entomology Laboratory, USDA, for all prey identifications and to Howard Evans and Arnold Menke for helpful comments on the manuscript.

\section{Literature Cited}

Alcock, J.

1975. Social interactions in the solitary wasp Cerceris simplex (Hymenoptera: Sphecidae). Behavior, 54: 142-152.

BoHART, G. E.

1972. Management of wild bees for the pollination of crops. Annu. Rev. Entomol., 17: 287-312.

1970. The Evolution of Parasitism Among Bees. Logan, Utah: Utah State Univ., $30 \mathrm{pp}$.

Brockmann, H. J. AND R. Dawkins

1979. Joint nesting in a digger wasp as an evolutionarily stable preadaptation to social life. Behavior, 71: 203-245.

EICKWORT, G. C.

1975. Gregarious nesting of the mason bee Hoplitis anthocopoides and the evolution of parasitism and sociality among megachilid bees. Evolution, 29: $142-150$.

Evans, H. E.

1966. The Comparative Ethology and Evolution of the Sand Wasps. Cambridge, Mass.: Harvard Univ. Press. 526 pp.

1959. Observations on the nesting behavior of digger wasps of the genus Ammophila. Amer. Mid. Natur.. 62: 449-473. 
Hicks, C. H.

1932. Notes on Sphex aberti (Hald.). Can. Entomol., 64: 145-151.

Malyshev, S. I.

1968. Genesis of the Hymenoptera and the Phases of Their Evolution. London: Methuen. 319 pp.

Powell, J. A.

1964. Additions to the knowledge of the nesting behavior of North American Ammophila (Hymenoptera: Sphecidae). J. Kans. Entomol. Soc., 37: 240-258.

Tepedino, V. J., L. L. McDonald and R. Rothwell.

1979. Defense against parasitization in mud-nesting Hymenoptera: Can empty cells increase net reproductive output? Behav. Ecol. Sociobiol., 6: 99-104.

TSUNEKI, $\mathrm{K}$.

1963. Comparative studies on the nesting biology of the genus Sphex (s.l.) in east Asia (Hymenoptera: Sphecidae). Mem. Fac. Liberal Arts, Fukui Univ., 13: 13-78.

WHEELER, W. M.

1919. The parasitic Aculeata, a study in evolution. Proc. Amer. Philo. Soc., 58: $1-40$. 

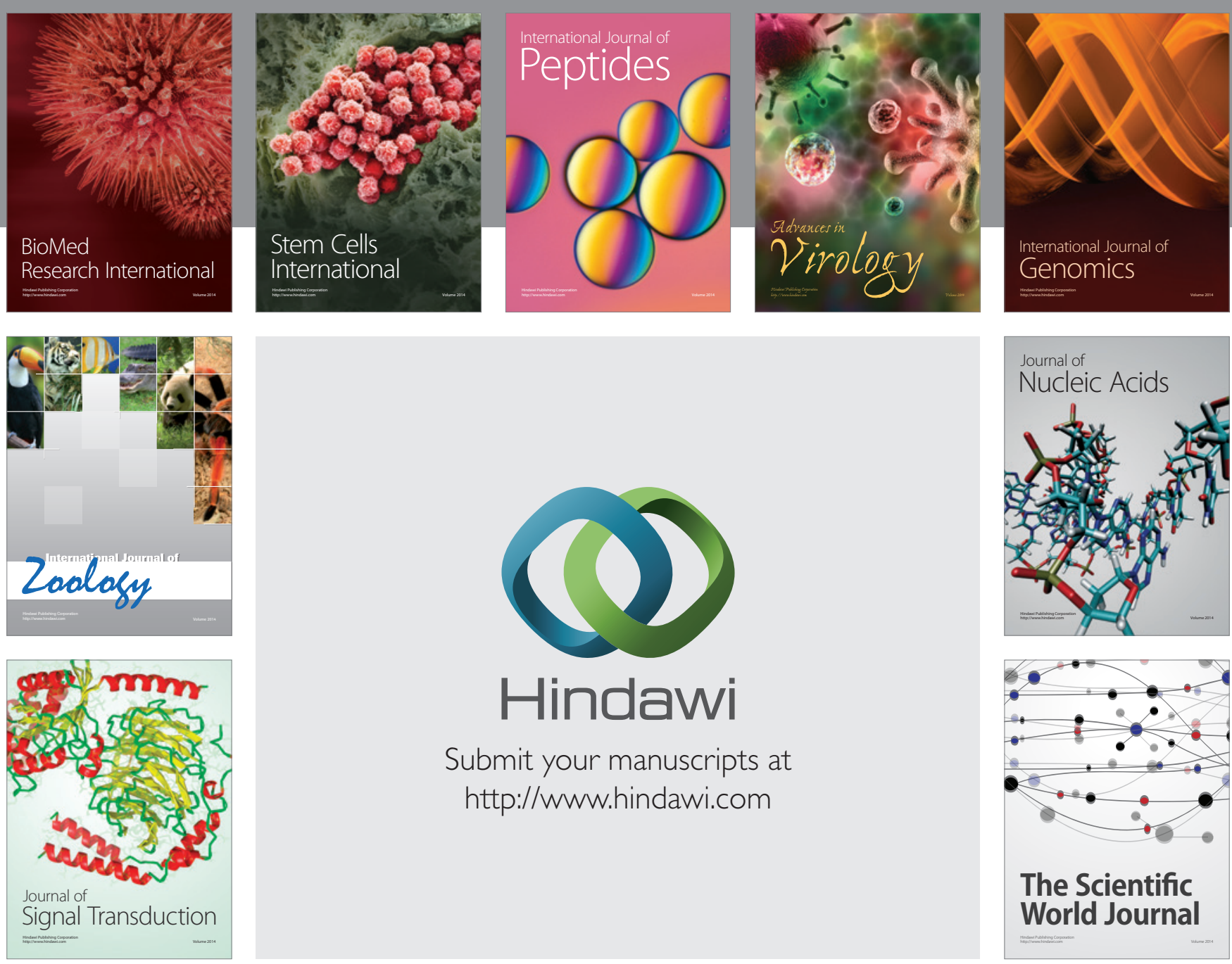

Submit your manuscripts at

http://www.hindawi.com
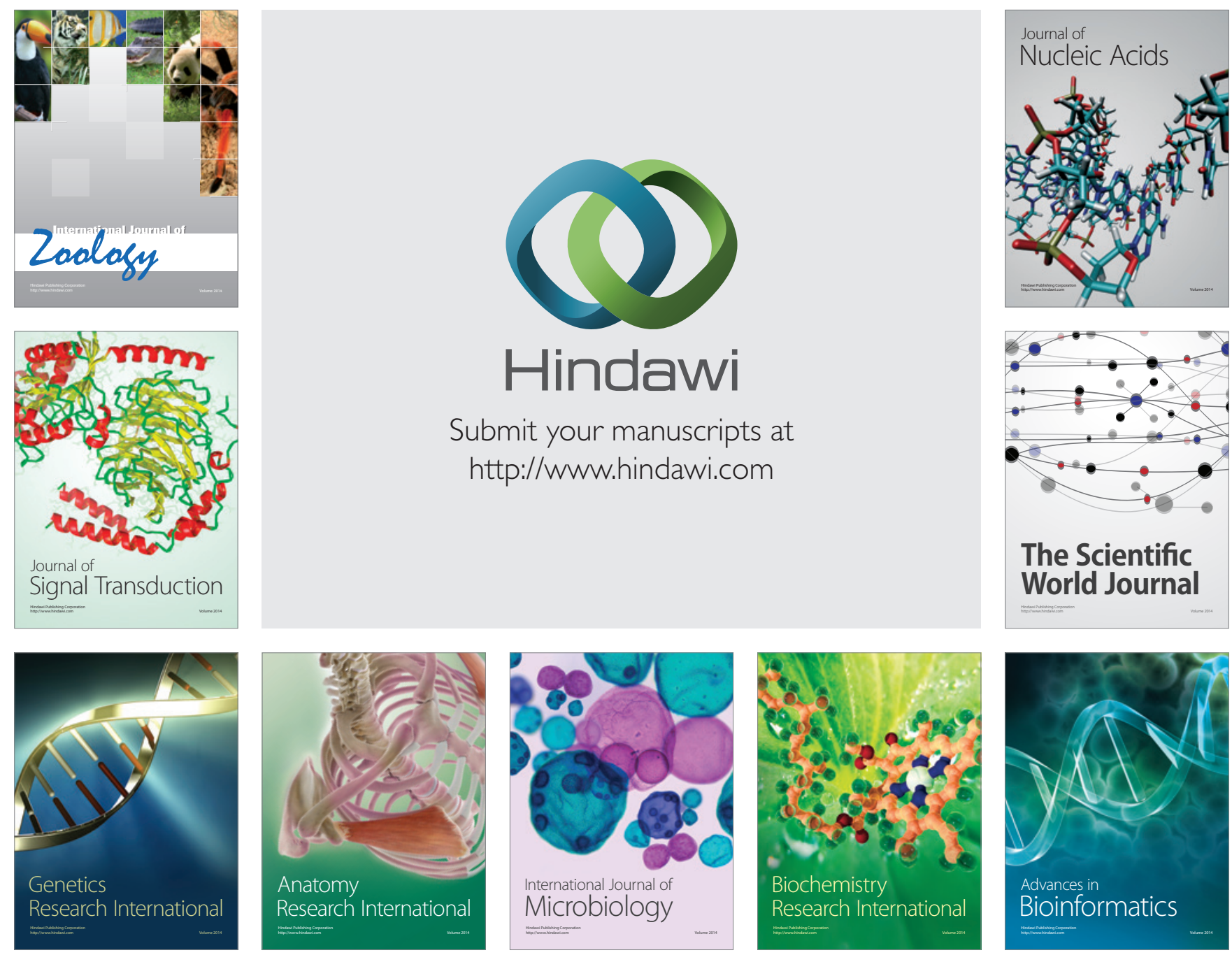

The Scientific World Journal
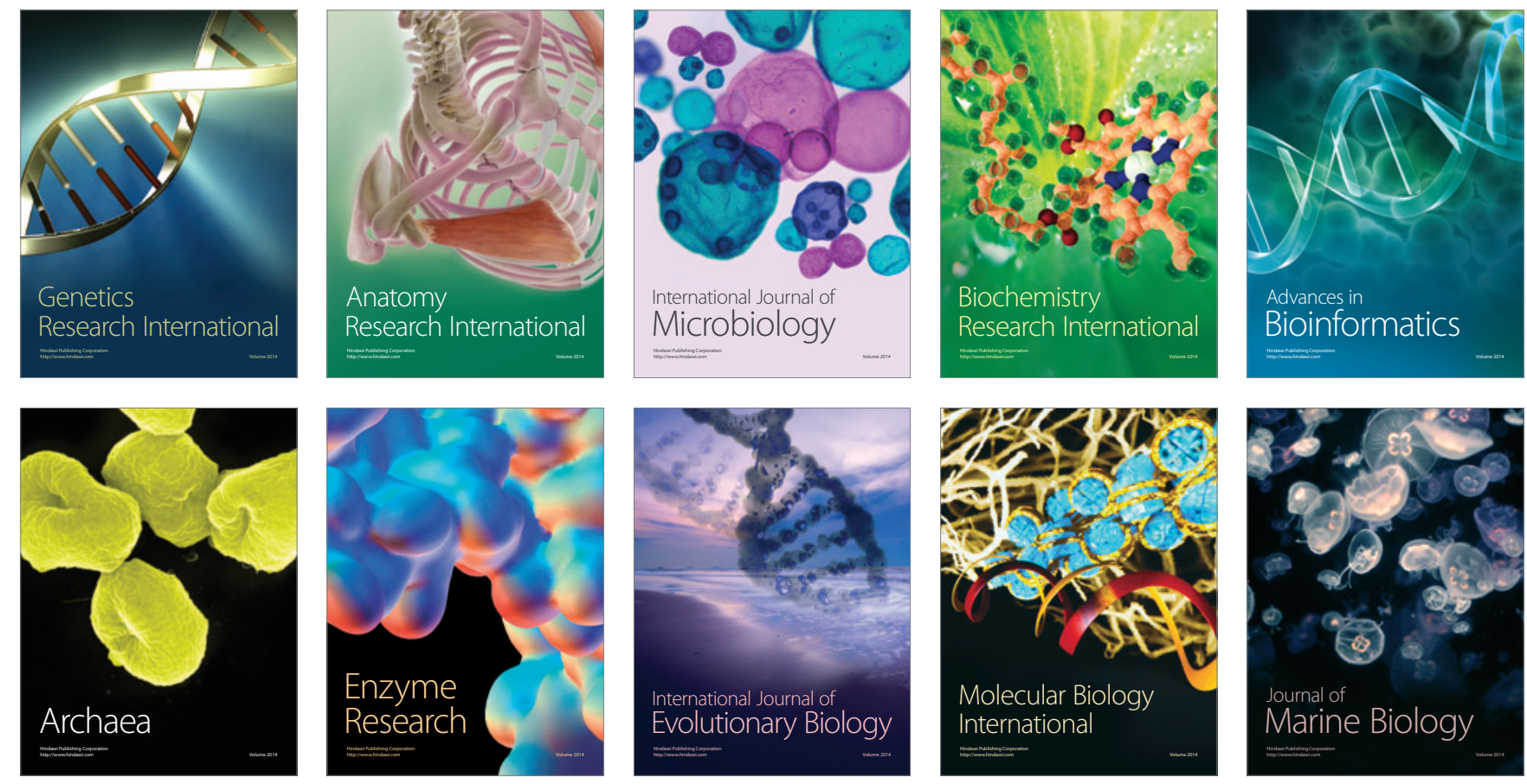